\title{
PERSEPSI IBU HAMIL TENTANG KEBUTUHAN ASAM FOLAT, ZAT BESI DAN KALSIUM SEBAGAI PERSIAPAN KEHAMILAN DI KOTA MATARAM DAN KABUPATEN LOMBOK BARAT
}

\author{
Irni Setyawati ${ }^{1)}$, Sri Handayani ${ }^{1)}$ \\ Email: erny.gunawan07@gmail.com \\ ${ }^{1)}$ Program Studi Kebidanan, STIKes Yarsi Mataram
}

\begin{abstract}
ABSTRAK
Survey Demografi dan Kesehatan Indonesia (SDKI) tahun 2012 menemukan komplikasi selama kehamilan secara nasional sebesar $24 \%$, sedangkan yang dimiliki provinsi Nusa Tenggara Barat (NTB) masih diatas angka nasional yaitu sebesar 33\%. Komplikasi selama kehamilan dapat disebabkan oleh berbagai macam faktor, salah satu diantaranya yaitu belum adanya persiapan kehamilan saat sebelum konsepsi. Perempuan dengan riwayat merariq di pulau Lombok tahun 2015 tidak melakukan persiapan kehamilan baik dari konsumsi suplemen dan perilaku kesehatannya. Tujuan dilakukannya penelitian ini yaitu untuk mengidentifikasi perbedaan persiapan kehamilan berdasarkan persepsi ibu tentang kebutuhan asam folat, zat besi dan kalsium di kota Mataram dan kabupaten Lombok Barat. Penelitian ini bersifat analitik komparatif dengan pendekatan retrospektif. Jumlah sampel yang diperoleh yaitu 64 orang. Teknik pengambilan sampel secara purposive sampling. Penelitian dilakukan di Puskesmas Kota Mataram dan Puskesmas kabupaten Lombok Barat pada bulan September - Oktober tahun 2017. Variabel diukur menggunakan kuesioner dan dianalisis dengan menggunakan uji Chi-Square. Sebagian besar responden tidak melakukan persiapan kehamilan dan berpersepsi perlu mengkonsumsi asam folat, namun tidak perlu mengkonsumsi zat besi dan kalsium. Terdapat perbedaan bermakna persiapan kehamilan antara ibu yang berpersepsi perlunya mengkonsumsi asam folat dan zat besi dengan nilai $\mathrm{p}<0,05$. Persepsi responden tentang perlunya mengkonsumsi asam folat, zat besi dan asam folat mempengaruhi persiapan kehamilan yang dilakukan oleh calon ibu. Diharapkan adanya penelitian lanjutan tentang faktor-faktor yang mempengaruhi persiapan kehamilan.
\end{abstract}

Kata kunci: persiapan kehamilan, asam folat, zat besi, kalsium

\begin{abstract}
The Indonesian Demographic and Health Survey (IDHS) in 2012 found complications during pregnancy nationally by $24 \%$, while those in the province of West Nusa Tenggara were still above the national figure of $33 \%$. Complications during pregnancy can be caused by various factors, one of which is the absence of pregnancy preparation before conception. Women with a history of merariq on Lombok in 2015 did not make preparations for pregnancy either from their supplemental consumption and health behavior. The purpose of this study was to identify differences in pregnancy preparation based on the mother's perception of the need for folic acid, iron and calcium in the city of Mataram and West Lombok regency. This study was comparative analytical with a retrospective approach. The number of samples obtained was 64 people. The sampling technique was purposive sampling. The study was conducted at the Health Center in Mataram City and West Lombok district in September - October 2017. Variables were measured using a questionnaire and analyzed using the Chi-Square test. Most respondents did not prepare for pregnancy and had the perception that they needed to consume folic acid, but did not need to consume iron and calcium. There were significant differences in preparation for pregnancy between mothers who perceived the need to consume folic acid and iron (value of $\mathrm{p}<0.05$ ). Respondents' perceptions of the need to consume folic acid, iron and folic acid affect pregnancy preparation conducted by mothers. It is expected that further research on the factors that influence pregnancy preparation.
\end{abstract}

Keywords: pregnancy preparation, folic acid, iron, calcium 


\section{A. LATAR BELAKANG}

Kehamilan merupakan peristiwa penting dalam sebuah keluarga khususnya ibu dan suami. Kondisi ibu dan janin sehat dan selamat menjadi tujuan akhir dari kehamilan. Untuk memperoleh keadaan tersebut diperlukan persiapan kehamilan. Persiapan kehamilan adalah tindakan pasangan usia subur menyiapkan fisik, mental, spiritual, dan sosial selama 3 atau 4 bulan sebelum kehamilan[1,2]. Tujuan dari persiapan kehamilan ini salah satunya yaitu dapat mengurangi risiko komplikasi kehamilan dan kelainan pada janin[3]. Komplikasi kehamilan merupakan masalah kesehatan yang sering terjadi selama kehamilan dan berdampak pada kesehatan ibu, kesehatan bayi ketika dilahirkan atau keduanya. Persentase komplikasi selama kehamilan secara nasional sebesar $24 \%$, sedangkan persentase komplikasi selama kehamilan yang dimiliki provinsi Nusa Tenggara Barat (NTB) masih diatas angka nasional yaitu sebesar 33\%[4]. Profil kesehatan provinsi NTB tahun 2016 menemukan bahwa Kabupaten Lombok Barat mempunyai 13,12\% komplikasi kehamilan dari 23.394 kejadian dan Kota Mataram 8,3\%[5].

Komplikasi selama kehamilan dapat disebabkan oleh berbagai macam faktor, salah satu diantaranya yaitu belum adanya persiapan kehamilan saat masa sebelum konsepsi. Masa sebelum konsepsi merupakan masa yang sangat penting untuk kesehatan ibu hamil dan bayi. Saat masa sebelum konsepsi inilah calon ibu dipersiapkan status nutrisinya, kebutuhan suplemen asam folat, perilaku, lingkungan dan pekerjaan yang berbahaya, karena beberapa faktor diatas dapat mempengaruhi keadaan sekitar uterus dan perkembangan janin[6].

Konsumsi asam folat sebelum hamil dapat mengurangi risiko spina bifida atau defek pada saluran saraf lainnya pada bayi[1]. Zat besi dapat mengurangi risiko anemia kekurangan zat besi saat hamil. Anemia ini merupakan penyebab utama anemia pada kehamilan[1]. Camargo, et al menyatakan bahwa kalsium penting untuk kesehatan tulang ibu dan janin, asupan kalsium yang cukup dapat mengurangi kejadian hipertensi selama kehamilan[7].

Penelitian tentang persiapan kehamilan pada perempuan dengan riwayat merariq di pulau Lombok yang dilakukan pada tahun 2015 memperoleh hasil bahwa sebagian besar responden tidak melakukan persiapan kehamilan baik dari konsumsi suplemen seperti multivitamin, vitamin $\mathrm{C}$, vitamin $\mathrm{D}$, omega 3, zinc, asam folat, zat besi, maupun multivitamin khusus, dan perilaku kesehatannya[8].

Berdasarkan hal tersebut di atas, tujuan dilakukannya penelitian ini yaitu untuk mengidentifikasi persepsi ibu hamil tentang konsumsi asam folat, zat besi dan kalsium sebagai persiapan kehamilan di kota Mataram dan kabupaten Lombok Barat.

\section{B. METODE PENELITIAN}

Rancangan penelitian ini adalah kuantitatif bersifat studi analitik komparatif dengan pendekatan retrospektif. Jumlah sampel yang diperoleh yaitu 64 orang. Teknik pengambilan sampel pada penelitian ini secara purposive sampling. Terdapat dua Puskesmas yang akan digunakan sebagai tempat penelitian, yaitu Puskesmas Ampenan Kota Mataram dan Puskesmas Gunungsari kabupaten Lombok Barat pada bulan September - Oktober tahun 2017.

Definisi operasional dari variabel terikat persiapan kehamilan yaitu persiapan fisik dan psikologis yang dilakukan ibu hamil selama minimal 3 bulan sebelum didiagnosis hamil oleh tenaga kesehatan dengan parameter konsumsi suplemen dan perilaku kesehatan untuk persiapan kehamilan, diukur dengan menggunakan kuesioner $[6,9,10,11]$. Variabel bebas yang diteliti meliputi persepsi ibu hamil tentang konsumsi asam folat, zat besi, dan kalsium sebelum hamil, diukur dengan menggunakan kuesioner. Data dianalisis dengan menggunakan uji Chi-Square. 


\section{HASIL DAN PEMBAHASAN}

Distribusi frekuensi persiapan kehamilan responden ditunjukkan pada tabel di bawah ini:

Tabel 1. Distribusi frekuensi persiapan kehamilan responden di Puskesmas kota Mataram dan kabupaten Lombok Barat tahun 2017

\begin{tabular}{|c|l|c|c|}
\hline \multirow{2}{*}{ No } & \multirow{2}{*}{ Persiapan Kehamilan } & \multicolumn{2}{|c|}{ Frekuensi } \\
\cline { 3 - 4 } & & $\mathrm{N}$ & $\%$ \\
\hline 1 & Melakukan & 18 & 28,13 \\
\hline 2 & Tidak melakukan & 46 & 71,87 \\
\hline & Total & 64 & 100 \\
\hline
\end{tabular}

Berdasarkan tabel 1 di atas, dapat dilihat bahwa sebagian besar responden $(71,87 \%)$ tidak melakukan persiapan kehamilan baik fisik maupun psikologis selama 3 bulan sebelum hamil.

Hasil penelitian Oktalia pada tahun 2015 yang dilakukan di wilayah kerja Puskesmas Kecamatan Cipayung Jakarta Timur menemukan bahwa sebagian besar pasangan usia subur $(64,6 \%)$ tidak menyiapkan kehamilannya[12].

Centers for Diasease Control and Prevention (CDC) mendefinisikan bahwa perawatan persiapan kehamilan merupakan serangkaian intervensi yang ditujukan untuk menemukan dan memodifikasi risiko biomedis, perilaku, dan sosial pada hasil akhir kehamilan atau kesehatan wanita melalui pencegahan dan penatalaksanaan[3].

Distribusi frekuensi persepsi responden tentang konsumsi asam folat, zat besi, dan kalsium sebelum hamil ditunjukkan pada tabel di bawah ini:

Tabel 2. Distribusi frekuensi persepsi responden tentang konsumsi asam folat, zat besi, dan kalsium di Puskesmas kota Mataram dan kabupaten Lombok Barat tahun 2017

\begin{tabular}{|c|l|c|c|}
\hline \multirow{2}{*}{ No } & \multirow{2}{*}{ Persepsi responden } & \multicolumn{2}{|c|}{ Frekuensi } \\
\cline { 2 - 4 } & & N & $\%$ \\
\hline 1 & Konsumsi asam folat & \multicolumn{2}{|c|}{} \\
\cline { 2 - 4 } & Ya & 34 & 53,1 \\
\cline { 2 - 4 } & Tidak & 30 & 46,9 \\
\hline 2 & Konsumsi zat besi & \multicolumn{2}{|}{} \\
\cline { 2 - 4 } & Ya & 28 & 43,8 \\
\cline { 2 - 4 } & Tidak & 36 & 56,3 \\
\hline 3 & Konsumsi kalsium & 28 & 43,8 \\
\cline { 2 - 4 } & Ya & 36 & 56,3 \\
\cline { 2 - 4 } & Tidak & \multicolumn{2}{|c}{} \\
\hline
\end{tabular}

Berdasarkan tabel 2 di atas, dapat dilihat sebagian besar responden $(53,1 \%)$ berpersepsi bahwa seorang perempuan yang akan hamil harus mengkonsumsi asam folat, 56,3\% responden berpersepsi bahwa tidak harus mengkonsumsi zat besi dan kalsium.

Robin menyatakan persepsi sebagai suatu proses dimana seseorang mengorganisasikan dan menginterpretasikan sensasi yang dirasakan dengan tujuan memberi makna terhadap lingkungannya[13].

Tabel 3. Perbedaan persiapan kehamilan berdasarkan persepsi tentang konsumsi asam folat, zat besi, dan kalsium di Puskesmas kota Mataram dan kabupaten Lombok Barat tahun 2017

\begin{tabular}{|c|c|c|c|c|c|}
\hline \multirow{3}{*}{$\begin{array}{l}\text { Persepsi } \\
\text { responden }\end{array}$} & \multicolumn{4}{|c|}{ Persiapan kehamilan } & \multirow{3}{*}{$\rho$} \\
\hline & \multicolumn{2}{|c|}{ Melakukan } & \multicolumn{2}{|c|}{ Tidak } & \\
\hline & $\mathrm{N}$ & $\%$ & $\mathrm{~N}$ & $\%$ & \\
\hline $\begin{array}{l}\text { Konsumsi } \\
\text { asam folat }\end{array}$ & & & & & 0,01 \\
\hline $\mathrm{Ya}$ & 14 & 77,8 & 20 & 43,5 & \\
\hline Tidak & 4 & 22,2 & 26 & 56,5 & \\
\hline $\begin{array}{l}\text { Konsumsi zat } \\
\text { besi }\end{array}$ & & & & & 0,02 \\
\hline Ya & 12 & 66,7 & 16 & 34,8 & \\
\hline Tidak & 6 & 33,3 & 30 & 65,2 & \\
\hline $\begin{array}{l}\text { Konsumsi } \\
\text { kalsium }\end{array}$ & & & & & 0,53 \\
\hline $\mathrm{Ya}$ & 9 & 50 & 19 & 41,3 & \\
\hline Tidak & 9 & 50 & 27 & 58,7 & \\
\hline
\end{tabular}

Tabel 3 di atas menunjukkan bahwa terdapat perbedaan bermakna persiapan kehamilan antara responden yang berpersepsi perlunya mengkonsumsi asam folat dan yang tidak dengan nilai $\rho: 0,01 \quad(\rho<0,05)$, antara responden yang berpersepsi perlunya mengkonsumsi zat besi dan yang tidak dengan nilai $\rho: 0,02$, sedangkan tidak terdapat perbedaan persiapan kehamilan antara responden yang berpersepsi perlunya mengkonsumsi kalsium dan yang tidak.

Persiapan kehamilan yang dilakukan oleh responden merupakan hasil antara stimulus dengan respons yang dipengaruhi oleh faktor dari dalam dan luar.

Beberapa faktor yang mempengaruhi perilaku menurut Green yaitu faktor predisposisi yang meliputi pengetahuan, sikap, 
keyakinan, kepercayaan, nilai-nilai, tradisi, dan sebagainya, faktor pemungkin yang meliputi sarana dan prasarana, dan faktor penguat[13].

Persepsi responden tentang perlunya mengkonsumsi asam folat, zat besi dan asam folat mempengaruhi persiapan kehamilan yang dilakukan oleh calon ibu.

Persepsi responden dapat dipengaruhi oleh pengetahuan atau pengalaman ibu hamil. Pengetahuan ibu dapat diperoleh melalui pengalaman hamil sebelumnya atau informasi yang diperoleh dari tenaga kesehatan Puskesmas tempat ibu memeriksakan kehamilannya yang terdahulu.

Penelitian yang dilakukan oleh Goshu, et al di Ethiopia tahun 2016 menemukan bahwa $15,9 \%$ dari 422 wanita usia reproduksi mempunyai kesadaran yang baik terhadap suplemen asam folat sebelum hamil[14].

Asam folat merupakan suatu koenzim dalam metabolisme asam nukleat atau asam amino. Riset menunjukkan bahwa asupan asam folat yang tidak adekuat erat kaitannya dengan defek tuba neural pada perkembangan janin[1]. Untuk mengurangi risiko tersebut disarankan suplemen asam folat $400 \mathrm{mcg}$ per hari[1,15], namun bagi wanita yang sebelumnya telah memiliki bayi dengan defek tuba neural, dosis asam folat yang direkomendasikan ialah $4 \mathrm{gr}$ setiap hari selama sedikitnya satu bulan sebelum konsepsi dan dilanjutkan selama 12 minggu kehamilan[1].

Zat besi adalah elemen logam yang digunakan oleh tubuh terutama untuk membuat hemoglobin, komponen dalam sel darah merah yang bertanggung jawab dalam pengangkutan oksigen ke seluruh jaringan tubuh. Defisiensi zat besi dapat menimbulkan anemia. Untuk mengurangi risiko tersebut disarankan konsumsi zat besi $18 \mathrm{mg}$ per hari[1].

Kalsium sangat penting untuk pembentukan, perkembangan, pemeliharaan gigi, dan tulang ibu dan janin. Camargo et al berpendapat kalsium dapat mengurangi kejadian hipertensi selama kehamilan[1,7] Penelitian tentang tingkat kecukupan kalsium pada ibu hamil di Jember tahun 2016 menemukan bahwa sebagian besar ibu hamil (81,2\% dari 92 responden) tidak dapat memenuhi kebutuhan kalsium yang seharusnya didapat dari konsumsi pangan harian[7]. Asupan kalsium yang saat ini direkomendasikan pada wanita sebelum hamil yaitu $1300 \mathrm{mg}$ per hari[1].

\section{KESIMPULAN}

Sebagian besar responden tidak melakukan persiapan kehamilan dan berpersepsi perlu mengkonsumsi asam folat dan tidak mengkonsumsi zat besi. Terdapat perbedaan bermakna persiapan kehamilan antara responden yang berpersepsi perlunya mengkonsumsi asam folat, zat besi dan yang tidak, sedangkan tidak terdapat perbedaan persiapan kehamilan antara responden yang berpersepsi perlunya mengkonsumsi kalsium dan yang tidak.

Dari kesimpulan di atas, perlu dilakukan pendidikan kesehatan tentang pentingnya persiapan kehamilan dan penelitian lanjutan tentang faktor-faktor yang mempengaruhi persiapan kehamilan.

\section{E. UCAPAN TERIMA KASIH}

Terima kasih disampaikan kepada responden, Pimpinan UPT. BLUD Puskesmas Gunungsari kabupaten Lombok Barat beserta bidan koordinator dan pelaksana, Pimpinan UPT. BLUD Puskesmas Ampenan kota Mataram beserta bidan koordinator dan pelaksana.

\section{DAFTAR PUSTAKA}

[1] Varney H, Kriebs JM, Gegor, CL (2006), Buku ajar asuhan kebidanan edisi 4 volume 1, EGC, Jakarta.

[2] Medforth J (editor) (2011), Kebidanan Oxford: dari Bidan untuk Bidan, EGC, Jakarta.

[3] Cunningham FG (2012), Obstetri Williams edisi 23 volume 1, EGC, Jakarta. 
[4] BKKBN, BPS, Kementrian Kesehatan RI, Measure DHS ICF Internasional (2013), Survey demografi dan kesehatan Indonesia 2012, [diunduh tanggal 10 Agustus 2014], tersedia dari www.kesga.kemkes.go.id

[5] Dinas Kesehatan Provinsi NTB (2017), Profil Kesehatan Provinsi NTB tahun 2016, [diunduh tanggal 20 September 2017], tersedia dari www.depkes.go.id

[6] Stephenson J, Patel D, Barret G, Howden B, Cops A, et al (2014), How do women prepare for pregnancy? Preconception experiences of women attending antenatal service and views of health professionals, PloS One 9 (7) tersedia dari www.journal.pone

[7] Purnasari G, Briawan D, Dwiriani CM (2016), Asupan kalsium dan tingkat kecukupan kalsium pada ibu hamil di kabupaten Jember, Jurnal MKMI vol 12 (4), 261-268

[8] Setyawati I, Aryani NP, Dwijayanti W (2017), Persiapan kehamilan pada perempuan dengan riwayat merariq di pulau Lombok, Prosiding seminar nasional kebidanan dan call for paper peningkatan kualitas pelayanan kebidanan melalui pendekatan holistik, 9-16

[9] Ayalew Y, Mulat A, Dile M and Simegn A (2017), Women's knowledge and associated factors in preconception care in adet, west gojjam, north west Ethiopia: a community based cross sectional study, Reproductive Health 14 (15), 1-10

[10]Jack BW, et al (2008), The clinical content of preconception care: an overview and preparation of this supplement, AJOG, S267-S279.

[11]Kementrian Kesehatan RI (2015), Lembar balik kesehatan reproduksi dan seksual bagi calon pengantin, Kementrian Kesehatan RI, Jakarta.

[12]Oktalia J, Herizasyam (2016), Kesiapan ibu menghadapi kehamilan dan faktorfaktor yang mempengaruhinya, Jurnal Ilmu dan Teknologi Kesehatan volume 3 (2), 147-159.

[13]Notoadmodjo S (2010), Promosi kesehatan teori dan aplikasi, PT. Rineka Cipta, Jakarta.

[14]Goshu YA, Liyeh TM, Ayele AS, Zeleke LB, Kassie YT (2018), Women's awareness and associated factors on preconception folic acid supplementation in adet, northwestern Ethiopia, 2016: Implication of reproductive health, Journal of nutrition and metabolism volume 2018, 1-7.

[15]Farahi, N and Zolotor, A (2013), Recommendations for Preconception Counseling and Care, AAFP Journal vol 88 (8), 499-506. 